\title{
Triple histology of an extracted polytef (gore-tex) implant
}

\author{
Ana Maria Abreu Velez ${ }^{1}$, William E. Silver ${ }^{2}$, Michael S. Howard ${ }^{1}$ \\ ${ }^{1}$ Georgia Dermatopathology Associates, Atlanta, Georgia, USA, ${ }^{2}$ Silver Plastic Surgery Center, Atlanta, Georgia USA
}

Corresponding author: Ana Maria Abreu Velez, M.D., Ph.D., E-mail: abreuvelez@yahoo.com

Sir,

Fillers, including Gore-Tex, have been long utilized for reconstructive procedures as well as for esthetic purposes. We report a 46 year female, who presented to the plastic surgeon to remove a previous nasolabial implant. The tissue was removed and examined using hematoxylin and eosin staining. Three histologic patterns were seen: 1) encapsulation around a large part of the material without giant cells, nor inflammation; 2) peripheral colonization by fibrous tissue, blending with normal soft tissue, and 3) thickening of adjacent skin. We thus document a mixed histologic pattern, featuring a partial peri-implant fibrous capsule, fibrous tissue merging with surrounding normal soft tissue and focal skin thickening.

Case: A 46 female patient visited the plastic surgeon to obtain an esthetic repair, secondary to a 23 year old surgical lip and nasolabial groove correction. The patient told the doctor that she had a previous Gore-Tex implant, which she wanted to remove and replace with Restylane. Informed consent was obtained. The plastic surgeon removed the Gore-Tex material [1-3], and sent it for histologic examination. Our H\&E staining was performed as previously described [4].

Review of the H\&E sections demonstrated histologic alterations around the foreign material. Fibrous encapsulation was seen around a large part of the material; however, neither foreign body giant cells nor inflammation were noted (Fig. 1). In other areas, the porous Gore-Tex mesh displayed peripheral fibrous tissue, merging with normal tissue; other parts of the specimen demonstrated thickening in adjacent skin.

Gore-Tex is known to be a safe implant material [1-3]. However, its use may lead to clinical problems. The

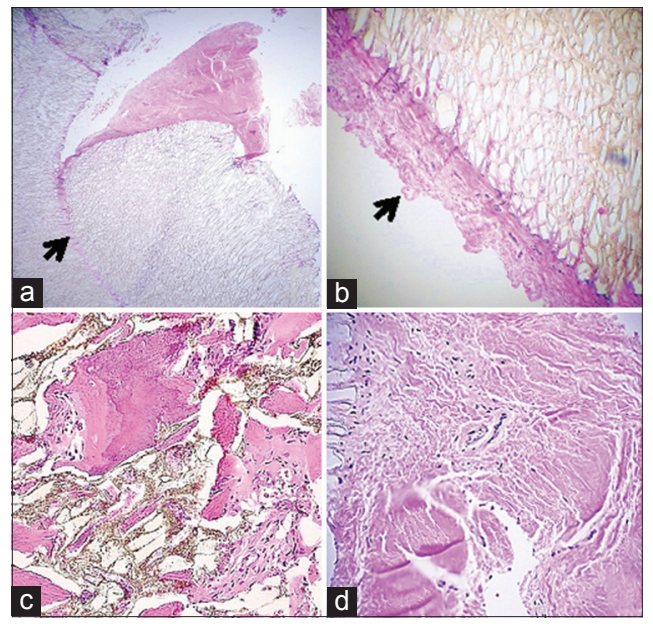

Figure 1: (a-d) Histologic changes associated with the Gore-Tex graft, utilizing H\&E staining. In ( $a$ and $b$ ) we highlight encapsulation of the porous Gore-Tex material at 100x and 400x, respectively (black arrows). In (c) we highlight Gore-Tex graft material, surrounded by fibrous tissue ingrowth. In (d) we document a thickened skin dermis, present around one side of the extracted Gore-Tex graft.

nasolabial folds represent facial sites frequently complained about by esthetic patients in all age groups, especially when aging. Gore-Tex was commonly used in the 1990s for a few esthetic surgeries, including lip augmentation. Gore-Tex has also been used in other procedures including rhinophasty; laryngoplasty; artificial tracheal implants; tendon, vascular and heart valve reconstructions; cardiac bypass grafts; aorticpulmonary shunts; mandibular augmentation and periodontal procedures [1-3].

More recently, modern fillers including Restylane, Radiesse, Juvederm ${ }^{\circledR}$, Voluma, Belotero, Perlane and Sculptra have become available. Many patients currently visit plastic surgeons and dermatologists, requesting removal of previous Gore-Tex grafts with such a modern replacement.

\footnotetext{
How to cite this article: Velez AMA, Silver WE, Howard MS. Triple histology of an extracted polytef (gore-tex) implant. Our Dermatol Online. 2017;8(4):501-502.

Submission: 10.10.2016; Acceptance: 03.12.2016

DOI: 10.7241 /ourd.20174.144
} 
Our findings are consistent with selected previously documented histologic features, including fibrous tissue interfacing with normal soft tissue, and the changes in skin thickness. However, in contradistinction to one previous report [5], we observed no calcifications, inflammation or foreign body giant cells. In addition, we did observe a partial peri-implant fibrous capsule. We conclude that in our case, the surrounding tissue around the Gore-Tex implant demonstrated no notable inflammation, and that a peri-implant fibrous capsule was also present. Thus, we recommend that all removed implants be presented for histologic review.

\section{REFERENCES}

1. Conrad K, Reifen E. Gore-Tex implant as tissue filler in cheek-lip groove rejuvenation. J Otolaryngol. 1992;21:218-22.
2. Conrad K, MacDonald MR. Wide polytef (Gore-Tex) implants in lip augmentation and nasolabial groove correction. Arch Otolaryngol Head Neck Surg. 1996;122:664-70.

3. Jang TY, Choi JY, Jung DH, Park HJ, Lim SC. Histologic study of Gore-Tex removed after rhinoplasty. Laryngoscope. 2009;119:620-7.

4. Abreu Velez AM, Howard MS, Dejoseph LM. HAM56 and CD68 antigen presenting cells surrounding a sarcoidal granulomatous tattoo. North Am J Med Sci. 2011;3:475-77.

5. Trumpy IG, Roald B, Lyberg T. Soft tissue response to polytetrafluoroethylene and silicone rubber in humans: morphological and immunohistochemical observations. Scand J Plast Reconstr Surg Hand Surg. 1997;31:295-301.

Copyright by Ana Maria Abreu Velez, et al. This is an open access article distributed under the terms of the Creative Commons Attribution License, which permits unrestricted use, distribution, and reproduction in any medium, provided the original author and source are credited.

Source of Support: Georgia Dermatopathology Associates,

Conflict of Interest: None declared. 